\title{
Effect of peat quality on microbial greenhouse gas formation in an acidic fen
}

\author{
M. Reiche ${ }^{1}$, G. Gleixner ${ }^{2}$, and K. Küsel ${ }^{1}$ \\ ${ }^{1}$ Institute of Ecology, Friedrich Schiller University Jena, Dornburger Strasse 159, 07743 Jena, Germany \\ ${ }^{2}$ Max Planck Institute for Biogeochemistry, POB 100164 10, 07701 Jena, Germany
}

Received: 16 July 2009 - Published in Biogeosciences Discuss.: 3 September 2009

Revised: 10 December 2009 - Accepted: 21 December 2009 - Published: 13 January 2010

\begin{abstract}
Peatlands play an important role in the global carbon cycle and represent both an important stock of soil carbon and a substantial natural source of relevant greenhouse gases like $\mathrm{CO}_{2}$ and $\mathrm{CH}_{4}$. While it is known that the quality of organic matter affects microbial degradation and mineralization processes in peatlands, the manner in which the quality of peat organic matter affects the formation of $\mathrm{CO}_{2}$ and $\mathrm{CH}_{4}$ remains unclear. In this study we developed a fast and simple peat quality index in order to estimate its potential greenhouse gas formation by linking the thermo-degradability of peat with potential anaerobic $\mathrm{CO}_{2}$ and $\mathrm{CH}_{4}$ formation rates. Peat samples were obtained at several depths $(0-40 \mathrm{~cm})$ at four sampling locations from an acidic fen $(\mathrm{pH} \sim 4.7) . \mathrm{CO}_{2}$ and $\mathrm{CH}_{4}$ formation rates were highly spatially variable and depended on depth, sampling location, and the composition of pyrolysable organic matter. Peat samples active in $\mathrm{CO}_{2}$ and $\mathrm{CH}_{4}$ formation had a quality index above 1.35 , and the fraction of thermally labile pyrolyzable organic matter (comparable to easily available carbon substrates for microbial activity) obtained by thermogravimetry was above $35 \%$. Curie-point pyrolysis-gas chromatography/mass spectrometry mainly identified carbohydrates and lignin as pyrolysis products in these samples, indicating that undecomposed organic matter was found in this fraction. In contrast, lipids and unspecific pyrolysis products, which indicate recalcitrant and highly decomposed organic matter, correlated significantly with lower $\mathrm{CO}_{2}$ formation and reduced methanogenesis. Our results suggest that undecomposed organic matter is a prerequisite for $\mathrm{CH}_{4}$ and $\mathrm{CO}_{2}$ development in acidic fens. Furthermore, the new peat quality index should aide the estimation of potential greenhouse gas formation resulting from peatland restoration and permafrost thawing and help yield more robust models of trace gas fluxes from peatlands for climate change research.
\end{abstract}

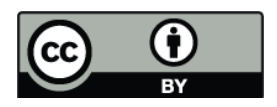

Correspondence to: K. Küsel (kirsten.kuesel@uni-jena.de)

\section{Introduction}

Growing peatlands maintain an imbalance between net primary production and decomposition, leading to the accumulation of large carbon $(\mathrm{C})$ stocks due to the slow mineralization of plant biomass (Clymo, 1983; Gorham, 1991; Botch et al., 1995; Turunen et al., 2002). However, peatlands are also known to emit greenhouse gases like $\mathrm{CO}_{2}$ and $\mathrm{CH}_{4}$ (i.e. Aselmann and Crutzen, 1989; Charman et al., 1999), which are also important indicators of total $\mathrm{C}$ mineralization (Bridgham and Richardson, 1992). As atmospheric concentrations of both $\mathrm{CO}_{2}$ and $\mathrm{CH}_{4}$ are increasing rapidly, with consequences for future global climate (Bridgham and Richardson, 1992; Houghton, 2005), it is crucially important to fully understand both sinks and sources in the global carbon cycle.

Measured emission and formation rates of $\mathrm{CO}_{2}$ and $\mathrm{CH}_{4}$ demonstrate strong spatial variation between peatland sites (i.e. Moore et al., 1990; Whalen and Reeburgh, 1990) which may result from such site-specific factors as temperature, oxygen availability and ground water level (Yavitt et al., 1987; Moore and Knowles, 1990; Bridgham and Richardson, 1992; Roulet et al., 1992a; Petrescu et al., 2008). Although there has been some success in relating water level and temperature to $\mathrm{CO}_{2}$ and $\mathrm{CH}_{4}$ emissions within particular wetlands (Roulet et al., 1992b; Walter and Heimann, 2000; Strack and Waddington, 2007; Petrescu et al., 2008), these variables are insufficient for predicting emissions across a variety of peatlands (Whiting and Chanton, 1993). Another important factor that influences the chemical composition, degradability of peat, and its potential for producing $\mathrm{CO}_{2}$ and $\mathrm{CH}_{4}$ is the botanical origin of the plant litter (Moore et al., 2007). For example, Carex peat contains much less cellulose and hemicellulose compared to Sphagnum peats (Bohlin et al., 1989). Because both carbohydrates are likely substrates for hydrolytic fermentation (Zeikus, 1983) these different peat types will likely also yield differing amounts of precursors for anaerobic $\mathrm{CO}_{2}$ formation and methanogenesis.

Published by Copernicus Publications on behalf of the European Geosciences Union. 
Although temperature, water saturation, redox conditions, vegetation, and degree of peat decomposition are often similar on a local scale, $\mathrm{CO}_{2}$ and $\mathrm{CH}_{4}$ formation rates are still often spatially variable at this scale and a peatland may include areas with negligible activity (Svensson and Rosswall, 1984; Whalen and Reeburgh, 1990; Reiche et al., 2008). Consequently, the factors listed above are not sufficient to explain $\mathrm{CO}_{2}$ and $\mathrm{CH}_{4}$ formation rates reliably on either large or small spatial scales. In order to reliably estimate the potential greenhouse gas formation of peat in general, a parameter based on both the quality and quantity of bioavailable organic matter present in peat, which should in turn control $\mathrm{CO}_{2}$ and $\mathrm{CH}_{4}$ formation (Yavitt and Lang, 1990; Bridgham and Richardson, 1992; Valentine et al., 1994; Christensen et al., 2003; Reiche et al., 2008), may be required. However, there is currently no common definition or widely accepted quantitative index of "organic matter quality" that can be used to determine potential greenhouse gas emission ( $\mathrm{Ru}$ bino et al., 2007).

Same previous investigations tried to develop thermalstability indices for the characterization of humic substances, composts or soil fractions and only few studies have focused on analyses of whole soil samples (e.g. Dell'Abate et al., 1998; Grisi et al., 1998; Dell'Abate et al., 2002, 2003; Lopez-Capel et al., 2005; Plante et al., 2005; Fernandez et al., 2008). However, there is a lack of knowledge about the relationship between biochemical and thermal stability (reviewed by Plante et al., 2009). A recent study demonstrated that thermogravimetry (TG) can easily estimate the decomposition potential of leaf litter in upland soils (Rubino et al., 2007). Based on these data, we conclude a relationship between litter composition and microbial $\mathrm{CO}_{2}$ formation as the proportion of thermal labile compounds and $\mathrm{CO}_{2}$ respiration rates decreased during an 8-month incubation period. In this study we applied the same technique to derive a quality index for peat organic matter. Using pyrolysis-gas chromatography/mass spectrometry (Py-GC/MS), we identified the biological precursors of pyrolysis products present in peat samples (Kracht and Gleixner, 2000). The peat quality index was then compared to anaerobic $\mathrm{CO}_{2}$ and $\mathrm{CH}_{4}$ formation rates to determine the influence of the chemical composition of peat on the extent of both gas forming processes. We hypothesized that peat with a higher proportion of thermally labile organic mater would correspond to higher potential $\mathrm{CO}_{2}$ and $\mathrm{CH}_{4}$ formation rates.

\section{Materials and methods}

\subsection{Peat sampling}

Samples were obtained from an acidic fen (Schlöppnerbrunnen, fen area: $0.8 \mathrm{ha}, \mathrm{pH} 4.7$ ) located in the northern Fichtelgebirge region in east-central Germany $\left(50^{\circ} 7^{\prime} 54^{\prime \prime} \mathrm{N}\right.$, $11^{\circ} 52^{\prime} 51^{\prime \prime} \mathrm{E}, 700 \mathrm{~m}$ above sea level) as previously de- scribed (Reiche et al., 2008). The mean annual precipitation at this site between 1995-2006 was approximately $953 \mathrm{~mm}$ and the mean annual air temperature was $6.1{ }^{\circ} \mathrm{C}$. The Schlöppnerbrunnen fen has an average peat accumulation of about $50 \mathrm{~cm}$ and soil is Histosol on granite bedrock. Vegetation is dominated by Carex canescens, Carex rostrata, Juncus effuses, Molinia caerulea, and Eriophorum vaginatum. Ground water moves through the fen from the north to the south (Paul et al., 2006), with higher water saturation in south than in the north due to a slight slope. Thus, the northern part of the fen is naturally affected by water table fluctuations during dry seasons. This fen has been studied in detail with respect to anaerobic microbial processes since 2001. Based on these earlier investigations, peat was sampled at four locations in November 2006, from the middle to the southern part of the fen, following the hydrological gradient. Sampling locations were named $\mathrm{C} 2, \mathrm{D} 2, \mathrm{sD} 1, \mathrm{M}$ according to previous investigations (Reiche et al., 2009). The maximum distance between $\mathrm{C} 2$ and $\mathrm{M}$ was approximately $25 \mathrm{~m}$. Peat obtained at $\mathrm{C} 2$ and D2 was dark brown to black in color and the degree of decomposition according to Von Post's humification scale (Clymo, 1983) was higher (moderately decomposed, H6-7) than for the brownish peat at sD1 and M (slightly to moderately decomposed $\mathrm{H} 3-5$ ) in the $0-40 \mathrm{~cm}$ depth zone, respectively. Peat samples from $0-40 \mathrm{~cm}$ depth were obtained using an $8 \mathrm{~cm}$ diameter peat corer. Fresh plant litter was removed from the top and cores were separated in $10 \mathrm{~cm}$ depth segments (I: $0-10 \mathrm{~cm}$, II: $10-20 \mathrm{~cm}$, III: $20-30 \mathrm{~cm}$, IV: 30 $40 \mathrm{~cm}$ ). Peat samples were then transported to the laboratory in airtight plastic bags at $4{ }^{\circ} \mathrm{C}$ and processed the same day.

\subsection{Microcosm incubations and headspace gas determination}

To study the formation of $\mathrm{CO}_{2}$ and $\mathrm{CH}_{4}, 20 \mathrm{~g}$ of peat (fresh wt) was placed into a sterile $180 \mathrm{~mL}$ incubation flask (Mueller \& Krempel, Buelach, Switzerland) in three replicates under a continuous flow of sterile argon. Flasks were closed with rubber stoppers and screw-caps and incubated in the dark with an initial overpressure of $\sim 100$ mbar at $15^{\circ} \mathrm{C}$. Headspace concentrations of $\mathrm{CO}_{2}$ and $\mathrm{CH}_{4}$ were determined every 2 to 3 days over a 31 day incubation period. Headspace gases were measured with Hewlett Packard Co. 5980 series II gas chromatographs according to Reiche et al. (2008). First, a sample volume of $100 \mu \mathrm{l}$ was obtained from the headspace of microcosms after shaking them to release gas trapped inside the peat. $\mathrm{CO}_{2}$ analysis was then carried out by a thermal conductivity detector and $\mathrm{CH}_{4}$ concentrations were determined with a flame ionization detector.

\subsection{Analytical techniques}

Fresh duplicate peat samples were dried at $105^{\circ} \mathrm{C}$ for $24 \mathrm{~h}$ to determine water content (WC) and than burned at $500^{\circ} \mathrm{C}$ for $4 \mathrm{~h}$ to calculate the ash content as loss on ignition (LOI). 
Total $\mathrm{P}, \mathrm{Fe}, \mathrm{Al}, \mathrm{Mg}, \mathrm{Ca}, \mathrm{S}, \mathrm{H}, \mathrm{N}$ and $\mathrm{C}$ of dried $\left(60^{\circ} \mathrm{C}\right.$ for $48 \mathrm{~h}$ ) and milled (Mixer Mill MM301, Retsch, Germany) peat samples were analyzed with an elemental analyzer (vario EL, Elementar, Germany), by flame atomic absorption spectrometry (Perkin Elmer, 3300, USA), or photometrically (Varian, Cary 1E, USA) after acid digestion (Reiche et al., 2008). Total bacteria in peat depth segments obtained at C2 and D2 were enumerated by the 4,6-diamidino2-phenylindole (DAPI) method as described in Reiche et al. (2008).

Approximately $5 \mathrm{mg}$ of each dried and milled peat sample (in two replicates) was analyzed by thermogravimetry (Mettler Toledo, TGA/SDTA 851e, Switzerland) (TG) (Pope and Judd, 1977). The mass loss at increasing temperatures $\left(10.2^{\circ} \mathrm{C} \mathrm{min}^{-1}\right)$ was measured under a continuous flow of argon from 60 to $850^{\circ} \mathrm{C}$ followed by a final combustion under oxygen at $850^{\circ} \mathrm{C}$ (Rubino et al., 2007). Pyrolysis under anoxic conditions was done first to estimate the amount of thermal labile compounds. Less condensed, thermolabile and oxygen-rich compounds, i.e. polysaccharides, amino acids and volatile lipids evolve first in the TG (up to $300^{\circ} \mathrm{C}$ ) by releasing intramolecular water. At higher temperature at about $500{ }^{\circ} \mathrm{C}$ more condensed materials and high boiling lipids and lignin are destructed. Final combustion was necessary to calculate the amount of formed and pre-existing char. For further calculations, mass loss was then normalized to total pyrolyzable matter (between 40 to $95 \%$, data not shown).

Curie-point pyrolysis-gas chromatography/mass spectrometry (Py-GC/MS) (Gleixner et al., 1999) was used to identify major pyrolysis products from selected peat samples (C2 I and III, D2 I, II and IV, M I and IV; two replicates each, $\sim 0.7 \mathrm{mg}$ of each sample) (Schulten and Gleixner, 1999). These peat samples were selected with respect to their differences in the peat quality index (described in Sect. 3.3). The samples used for Py-GC/MS cover the full span of the peat quality index and also samples with the highest rates of $\mathrm{CO}_{2}$ and $\mathrm{CH}_{4}$ formation rates were in this range. Py-GC/MS is a powerful technique to distinguish between plant derived "biodegradable" and more "humified" compounds. Pyrolysis products like furanes and substituted phenols that derive from carbohydrates and lignin, respectively, indicate the presence of plant material whereas alkanes and unspecific pyrolysis products like benzol, phenol or naphthalene indicate highly humified organic material (Gleixner et al., 1999; Rubino et al., 2007). Pyrolysis was carried out under helium for $9.9 \mathrm{~s}$ at $500{ }^{\circ} \mathrm{C}$ with a Curie point Pyrolyzer 0316 (Thermo Fisher, USA). Volatile pyrolysis products were separated by gas chromatography (HP 5890, Germany) with a BPX5 capillary column (length, $60 \mathrm{~m}$; inner diameter, $0.32 \mathrm{~mm}$; film thickness, $1 \mu \mathrm{m}$; SGE, Germany) and analyzed using an ion trap mass spectrometer (Thermo Fisher, GCQ, USA) (Steinbeiss et al., 2006).

\subsection{Calculations and statistics}

Potential rates for $\mathrm{CO}_{2}$ and $\mathrm{CH}_{4}$ formation were determined from the linear increase of headspace and dissolved gas concentrations, calculated from three replicates. $\mathrm{CH}_{4}$ formation rates were calculated as the average of the period after onset of methanogenesis. Peat samples were then grouped according to their $\mathrm{CH}_{4}$ and $\mathrm{CO}_{2}$ forming activities by hierarchical cluster analysis, using the Ward method, based on the Euclidean squared distances (SPSS 15.0, SPSS Inc., Chicago, Illinois, USA). Pearson's correlation coefficients $(r)$ were calculated to test for correlations of anaerobic $\mathrm{CO}_{2}$ and $\mathrm{CH}_{4}$ formation with chemical peat parameters (SPSS 15.0, SPSS Inc., Chicago, Illinois, USA).

Evaluation of mass spectra obtained by Py-GC/MS was performed according to Schulten and Gleixner (1999) and Kracht and Gleixner (2000) and was compared to spectral databases like Wiley 6.0 (McLafferty, 2001), the National Institute of Standards and Technology (NIST, 2002) and the Integrated Spectral Data Base System for Organic Compounds (AIST, 2001). Means of two replicates from the mass list of pyrolysis spectra, the relative abundances of representative precursor groups (lipids, carbohydrates, lignin, and unspecific pyrolysis products normalized to $1 \mathrm{~g}$ pyrolyzable sample), were calculated as the summed peak areas of individual pyrolysis products belonging to the same precursor group (Table 1).

\section{Results}

\subsection{Chemical properties of peat}

The $\mathrm{C}$ content of peat samples obtained from $\mathrm{C} 2$ and $\mathrm{D} 2$ increased from $36 \%$ at $0-10 \mathrm{~cm}$ depth to more than $50 \%$ at 30 $40 \mathrm{~cm}$ depth, respectively (Table 2). In contrast, amount of C decreased with increasing depth at sD1 and $\mathrm{M}$. H content and loss on ignition ranged from $1.4 \%$ to $6.7 \%$ and from $31 \%$ to $92 \%$, and increased at C2 and D2 with depth, but decreased over depth at the southern sampling locations SD1 and M (Table 2). Proportion of total $\mathrm{N}$ decreased at all sampling areas over depth and yielded concentrations from 2.1 to $0.5 \%$. Corresponding C: $\mathrm{N}$ ratios were lowest in the upper peat compared with deeper samples and ranged from 18 to 44 over the $0-40 \mathrm{~cm}$ depth profile. The WC in peat obtained in the northern areas $\mathrm{C} 2$ and $\mathrm{D} 2$ ranged from 76 to $87 \%$. At sD1 and M, WC decreased from over $91 \%$ in upper depth segments to less than $85 \%$ below. The peat samples were naturally saturated or near saturation. Variations in WC between northern and more southern samples were caused by different degrees of peat decomposition. At location SD1 in depth below $20 \mathrm{~cm}$ granite gravel from the bedrock decreased the relative water content as well. The highest amounts of total $\mathrm{Fe}$ and $\mathrm{Al}$ were obtained in the first depth segment of areas D2, sD1 and $\mathrm{M}$ and yielded up to 36.4 and $43.8 \mathrm{mg} \mathrm{g}$ (dry wt peat $)^{-1}$. 
Table 1. Retention time, peak identification, precursor groups, and mass spectrometric characteristics of major pyrolysis products present in selected peat samples (C2, D2, M, according to Fig. 4) obtained over depth $(0-40 \mathrm{~cm})$ of an acidic fen.

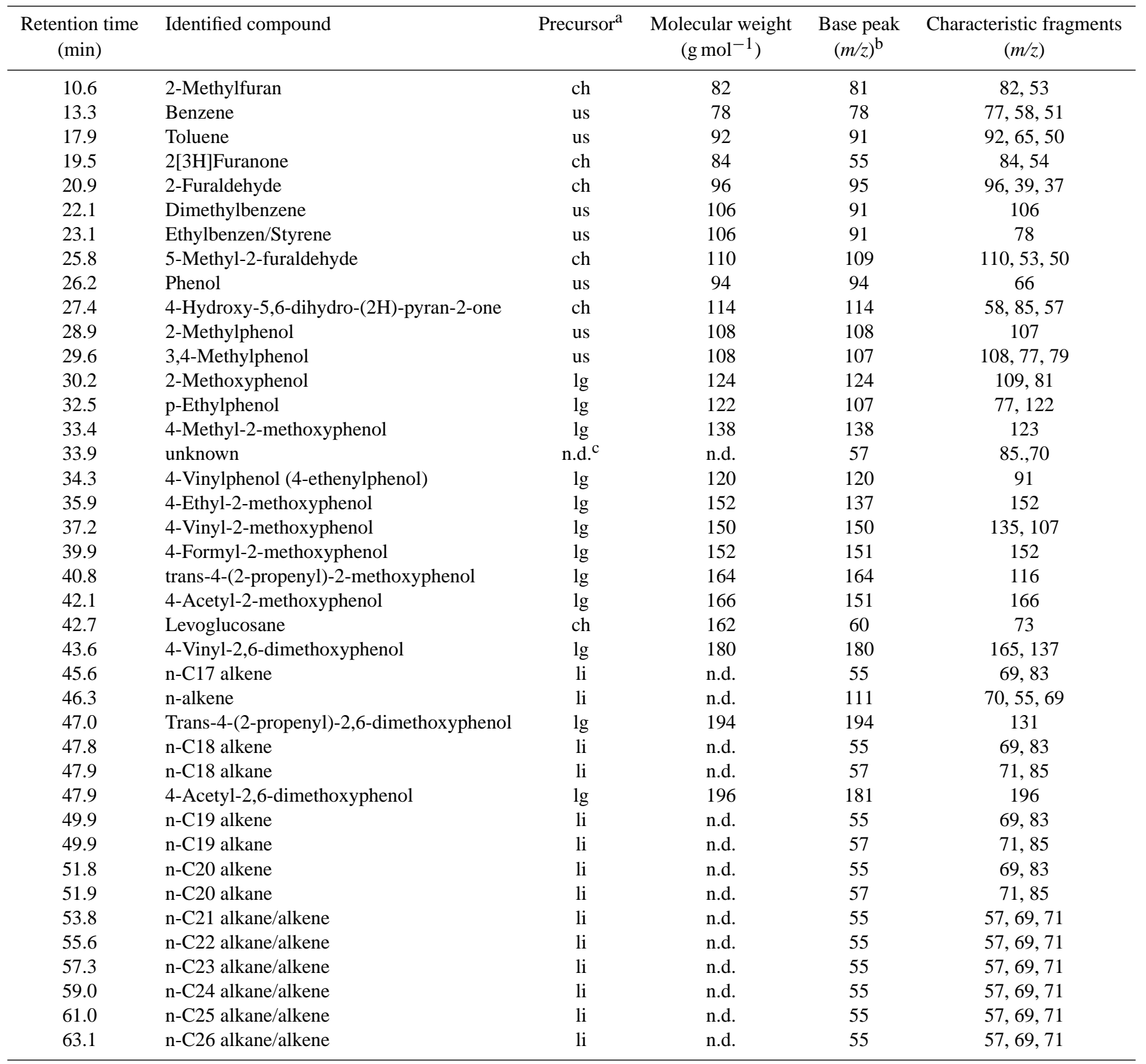

a ch = carbohydrates; $\lg =$ lignins; li = lipids; us = unspecific,

$\mathrm{b}$ mass-to-charge ratio,

c could not be determined 


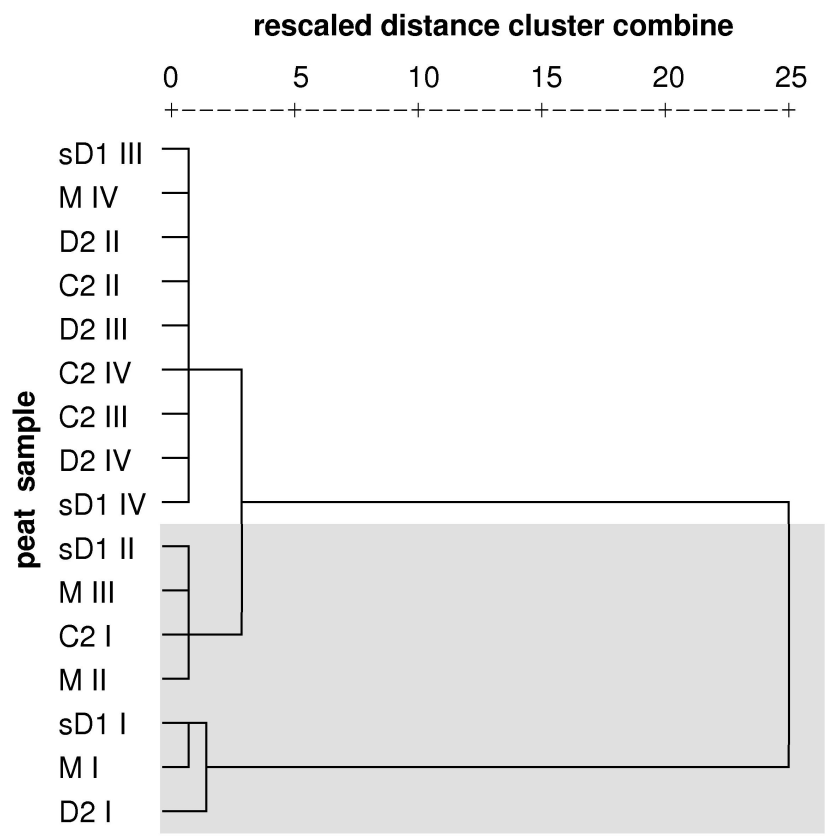

Fig. 1. Grouping of peat samples according to their $\mathrm{CO}_{2}$ and $\mathrm{CH}_{4}$ formation rates using hierarchical cluster analysis. The dendrograms were carried out using the Ward method, based on Euclidean squared distances. Samples were obtained at different areas along a hydrological gradient from an acidic fen (from the middle to the south $\mathrm{C} 2 \rightarrow \mathrm{D} 2 \rightarrow \mathrm{sD} 1 \rightarrow \mathrm{M}$ ) over 4 depths (I: $0-10 \mathrm{~cm}$, II: $10-20 \mathrm{~cm}$, III: $20-30 \mathrm{~cm}$, IV: $30-40 \mathrm{~cm}$ ). Peat samples yielding $\mathrm{CH}_{4}$ and $\mathrm{CO}_{2}$ formation rates above 0.1 and $1.2 \mu \mathrm{molg}$ (dry wt peat) $)^{-1} \mathrm{~d}^{-1}$, respectively, are highlighted (grey box).

Total concentrations of $\mathrm{Mg}, \mathrm{Ca}, \mathrm{P}$ and $\mathrm{S}$ were evenly distributed over depth and sampling location with mean values of $\sim 0.8,0.3$ and $1.3 \mathrm{mg} \mathrm{g}$ (dry wt peat $)^{-1}$ and $0.3 \%$, respectively (Table 2).

\subsection{Microbial formation of $\mathrm{CO}_{2}$ and $\mathrm{CH}_{4}$}

Peat soil $\mathrm{CO}_{2}$ and $\mathrm{CH}_{4}$ formation varied between sampling location and depth (Table 3). In general, anaerobic $\mathrm{CO}_{2}$ formation rates decreased strongly with increasing depth at all sampling areas with rates up to $12.7 \mu \mathrm{mol} \mathrm{CO}_{2} \mathrm{~g}$ (dry wt peat $)^{-1} \mathrm{~d}^{-1}$ in the upper-most peat segment and below $1.2 \mu \mathrm{mol} \mathrm{CO} 2 \mathrm{~g}$ (dry wt peat) ${ }^{-1} \mathrm{~d}^{-1}$ in deeper segments (Table 3). Microbial $\mathrm{CO}_{2}$ formation was highest at $\mathrm{M}$, the southernmost sampling area, compared with $\mathrm{C} 2, \mathrm{D} 2$, and $\mathrm{sD} 1$ peat samples. We found a positive correlation $(p<0.01)$ of anaerobic $\mathrm{CO}_{2}$ formation rates with total amounts of $\mathrm{Fe}(r=0.95)$, $\mathrm{Al}(r=0.92)$ and $\mathrm{Ca}(r=0.77)$ but not with WC, LOI, and total $\mathrm{P}, \mathrm{Mg}, \mathrm{C}, \mathrm{H}, \mathrm{N}$ and $\mathrm{S}(p>0.05)$.

Peat obtained from the southern areas $\mathrm{SD} 1$ and M showed a potential for $\mathrm{CH}_{4}$ formation with an apparent delay of 2 and 7 days, respectively, at all depths and initial methanogenesis could be detected below $20 \mathrm{~cm}$ depth at sD1. Methane formation rates ranged between 0.04 and $2.11 \mu \mathrm{mol} \mathrm{CH}_{4} \mathrm{~g}$ (dry wt peat $)^{-1} \mathrm{~d}^{-1}$ with maximum values in the $0-10 \mathrm{~cm}$ segment of sD1 and the 10-20 cm segment of M (Table 3). Peat obtained from $0-10 \mathrm{~cm}$ depth at $\mathrm{C} 2$ and $\mathrm{D} 2$ showed a potential formation of $\mathrm{CH}_{4}$, which started after an incubation of approximately 8 and 12 days, respectively. In depths below these, no formation of $\mathrm{CH}_{4}$ occurred during the prolonged incubation of 31 days. In general, the formation of $\mathrm{CH}_{4}$ was positively correlated with the peat WC $(r=0.58, p<0.05)$.

Peat samples were grouped according to their anaerobic $\mathrm{CO}_{2}$ and $\mathrm{CH}_{4}$ formation rates into two main clusters using hierarchical cluster analysis (Fig. 1). Rates for $\mathrm{CO}_{2}$ and $\mathrm{CH}_{4}$ formation below 1.2 and $0.1 \mu \mathrm{mol} g$ (dry wt peat) ${ }^{-1} \mathrm{~d}^{-1}$, respectively, indicated the threshold for less active or inactive peat while rates above suggested active peat. The low rates observed in the inactive, deeper peat segments of C2 and D2 could not be explained by differences in microbial cell numbers. Numbers of DAPI counted cells were approximately $10^{10}$ cells g [dry wt. peat] ${ }^{-1}$ and were similar at all depths.

In previous investigations we could show that similar patterns for anaerobic $\mathrm{CO}_{2}$ and $\mathrm{CH}_{4}$ formation rates occurred at the fen site independent from seasonal shifts from peat obtained at C2 and D2 from 0-40 cm depth during 2006 and 2007 (Reiche et al., 2008, 2009; and data not shown). Additionally, the pattern of aerobic $\mathrm{CO}_{2}$ formation rates of these peat samples, measured in oxic microcosms over an incubation period of 24 hours (Reiche et al., 2009), also supported this classification. In peat obtained from $0-10 \mathrm{~cm}$ depth at $\mathrm{C} 2$ and $\mathrm{D} 2$, aerobic $\mathrm{CO}_{2}$ formation rates were up to $1.4( \pm 0.5)$ times higher than anaerobic $\mathrm{CO}_{2}$ formation rates. Aerobic rates were lower in depths below $10 \mathrm{~cm}$ and approximated anaerobic rates. The high anaerobic $\mathrm{CO}_{2}$ and $\mathrm{CH}_{4}$ formation rates observed from peat sampled at $\mathrm{M}$ from $0-30 \mathrm{~cm}$ were also observed during 2001 and 2002 (Küsel et al., 2008).

\subsection{Peat quality}

The thermal degradability of organic matter of each peat sample was compared with the mass loss at distinct temperature intervals obtained by the TG technique. Four distinct temperature intervals were determined using variance analyses of mass loss spectra (mean of two replicates). The first temperature interval ranged from $205-360^{\circ} \mathrm{C}$ (rapid mass loss due to labile particulate organic matter; $\mathrm{pyOM}_{\text {labile}}$ ), the second from $365-480,{ }^{\circ} \mathrm{C}$ (slower mass loss due to more unspecific and more stable particulate organic matter), the third from $585-630,{ }^{\circ} \mathrm{C}$ (slow mass loss due to more recalcitrant particulate organic matter; $\mathrm{pyOM}_{\text {recalcitrant}}$ ), and the fourth was the sudden combustion under oxygen at $850^{\circ} \mathrm{C}$ (highly humified and inert particulate carbon compounds; pyOM $\left.{ }_{\text {inert }}\right)$. We tested different combinations of these four distinct temperature intervals to calculate a peat quality index with the highest correlation to measured anaerobic microbial $\mathrm{CO}_{2}$ and $\mathrm{CH}_{4}$ formation rates. The best fit equation for the quality index was expressed as ratio between the sum of mass 
Table 2. Chemical characteristics of peat obtained from an acidic fen ( $\mathrm{pH} 4.7)$ along a hydrological gradient (from the middle to the south $\mathrm{C} 2 \rightarrow \mathrm{D} 2 \rightarrow \mathrm{sD} 1 \rightarrow \mathrm{M}$ ) over 4 depths (I: 0-10 cm, II: 10-20 cm, III: 20-30 cm, and IV: 30-40 cm) in November 2006.

\begin{tabular}{|c|c|c|c|c|c|c|c|c|c|c|c|c|}
\hline $\begin{array}{l}\text { sample } \\
\text { depth }\end{array}$ & \multicolumn{2}{|c|}{$(\%)$} & \multicolumn{4}{|c|}{$\left(\right.$ mg g [dry wt peat] $\left.{ }^{-1}\right)$} & $\mathrm{Ca}_{\text {total }}$ & $\mathrm{S}_{\text {total }}$ & \multicolumn{2}{|c|}{$(\%)$} & $\mathrm{C}_{\text {total }}$ & $\begin{array}{l}\mathrm{C} / \mathrm{N} \\
\text { ratio }\end{array}$ \\
\hline $\mathrm{C} 2(\mathrm{I})^{\mathrm{c}}$ & 80.3 & 69.6 & 1.8 & 9.5 & 7.2 & 0.9 & 0.2 & 0.3 & 4.5 & 2.0 & 36.2 & 18.1 \\
\hline C2 (II) ${ }^{\mathrm{c}}$ & 81.7 & 83.3 & 1.5 & 5.9 & 4.1 & 0.3 & 0.1 & 0.3 & 5.4 & 2.1 & 47.3 & 22.5 \\
\hline $\mathrm{C} 2(\mathrm{III})^{\mathrm{c}}$ & 81.6 & 88.2 & 0.8 & 6.2 & 3.3 & 0.3 & 0.3 & 0.2 & 5.5 & 1.5 & 51.5 & 34.3 \\
\hline $\mathrm{C} 2(\mathrm{IV})^{\mathrm{c}}$ & 85.7 & 85.9 & 1.0 & 3.2 & 2.3 & 0.5 & 0.2 & 0.2 & 6.0 & 1.2 & 50.4 & 42.0 \\
\hline $\mathrm{D} 2(\mathrm{I})^{\mathrm{c}}$ & 87.0 & 74.6 & 1.5 & 36.4 & 43.8 & 0.7 & 0.6 & 0.3 & 4.5 & 1.7 & 36.4 & 21.4 \\
\hline D2 (II) ${ }^{\mathrm{c}}$ & 76.4 & 62.3 & 1.2 & 10.4 & 6.7 & 0.8 & 0.2 & 0.2 & 4.4 & 1.3 & 37.6 & 28.9 \\
\hline D2 (III) ${ }^{\mathrm{c}}$ & 79.8 & 91.6 & 0.8 & 5.6 & 4.3 & 0.2 & 0.3 & 0.3 & 6.7 & 1.3 & 55.3 & 42.5 \\
\hline $\mathrm{D} 2(\mathrm{IV})^{\mathrm{c}}$ & 84.4 & 85.4 & 1.0 & 4.7 & 3.4 & 0.5 & 0.2 & 0.3 & 6.0 & 1.3 & 51.0 & 39.2 \\
\hline sD1 (I) & 90.9 & 77.7 & 1.4 & 28.7 & 20.2 & 0.6 & 0.3 & 0.4 & 4.5 & 1.7 & 39.0 & 22.9 \\
\hline sD1 (II) & 90.3 & 74.8 & 1.5 & 5.7 & 2.8 & 1.0 & 0.3 & 0.5 & 4.7 & 1.4 & 37.7 & 26.9 \\
\hline sD1 (III) & 78.6 & 52.1 & 1.3 & 6.9 & 2.1 & 1.6 & 0.2 & 0.3 & 3.4 & 1.0 & 29.4 & 29.4 \\
\hline sD1 (IV) & 61.8 & 31.3 & 1.3 & 6.9 & 1.8 & 2.3 & 0.1 & 0.1 & 1.4 & 0.5 & 21.9 & 43.8 \\
\hline M (I) & 91.2 & 86.3 & 1.3 & 19.9 & 15.9 & 0.4 & 0.4 & 0.3 & 5.3 & 1.8 & 43.1 & 23.9 \\
\hline M (II) & 93.3 & 85.0 & 1.5 & 8.8 & 7.8 & 0.6 & 0.3 & 0.4 & 5.3 & 1.5 & 41.6 & 27.7 \\
\hline M (III) & 92.9 & 82.5 & 1.4 & 4.5 & 3.2 & 0.6 & 0.3 & 0.6 & 5.1 & 1.4 & 41.5 & 29.6 \\
\hline M (IV) & 85.9 & 68.8 & 1.5 & 7.1 & 3.8 & 1.1 & 0.3 & 0.5 & 4.6 & 1.3 & 37.6 & 28.9 \\
\hline
\end{tabular}

${ }^{\mathrm{a}}$ water content, ${ }^{\mathrm{b}}$ loss on ignition, ${ }^{\mathrm{c}}$ some data were obtained from Reiche et al. (2009)

Table 3. Anaerobic formation rates of $\mathrm{CO}_{2}$ and $\mathrm{CH}_{4}$, the onset of methanogenesis, and the peat quality index as ratio between the sum of thermal labile and recalcitrant $\mathrm{C}$-based compounds and inert carbon compounds, $\left(\mathrm{pyOM}_{\text {labile }}+\mathrm{pyOM}_{\mathrm{recalcitrant}}\right) / \mathrm{pyOM}_{\text {inert }}$ in peat obtained from an acidic fen ( $\mathrm{pH} 4.7$ ) along a hydrological gradient (from the middle to the south $\mathrm{C} 2 \rightarrow \mathrm{D} 2 \rightarrow \mathrm{sD} 1 \rightarrow \mathrm{M}$ ) over 4 depths $(\mathrm{I}: 0-10 \mathrm{~cm}$, II: $10-20 \mathrm{~cm}$, III: $20-30 \mathrm{~cm}$ and IV: $30-40 \mathrm{~cm})$ in November $2006(n=3)$.

\begin{tabular}{|c|c|c|c|c|}
\hline Sample & $\begin{array}{l}\mathrm{CO}_{2} \text { formation rate } \\
(\mu \mathrm{mol} g \text { [dry } \mathrm{w}\end{array}$ & $\begin{array}{l}\mathrm{CH}_{4} \text { formation rate } \\
\left.\text { peat }]^{-1} \mathrm{~d}^{-1}\right)\end{array}$ & $\begin{array}{c}\text { Onset of } \mathrm{CH}_{4} \text { formation } \\
\text { (day) }\end{array}$ & $\begin{array}{l}\text { Peat quality } \\
\text { index }\end{array}$ \\
\hline $\mathrm{C} 2(\mathrm{I})^{\mathrm{a}}$ & 4.3 & 0.14 & $\sim 8$ & 1.6 \\
\hline $\mathrm{C} 2(\mathrm{II})^{\mathrm{a}}$ & 1.0 & 0.00 & $\mathrm{n} \cdot \mathrm{a}^{\mathrm{b}}$ & 1.0 \\
\hline $\mathrm{C} 2(\mathrm{III})^{\mathrm{a}}$ & 0.8 & 0.00 & n.a. & 0.8 \\
\hline $\mathrm{C} 2(\mathrm{IV})^{\mathrm{a}}$ & 0.8 & 0.00 & n.a. & 1.0 \\
\hline $\mathrm{D} 2(\mathrm{I})^{\mathrm{a}}$ & 12.7 & 0.32 & $\sim 12$ & 1.7 \\
\hline $\mathrm{D} 2(\mathrm{II})^{\mathrm{a}}$ & 1.2 & 0.00 & n.a. & 1.2 \\
\hline D2 (III) ${ }^{\mathrm{a}}$ & 0.9 & 0.00 & n.a. & 1.0 \\
\hline D2 (IV) ${ }^{a}$ & 0.6 & 0.00 & n.a. & 0.9 \\
\hline sD1 (I) & 9.7 & 1.25 & $\sim 5$ & 1.7 \\
\hline sD1 (II) & 1.7 & 0.32 & $\sim 2$ & 1.4 \\
\hline sD1 (III) & 0.7 & 0.08 & 1 & 1.2 \\
\hline sD1 (IV) & 0.1 & 0.04 & 1 & 1.0 \\
\hline M (I) & 8.9 & 0.38 & $\sim 7$ & 1.8 \\
\hline M (II) & 4.9 & 2.11 & $\sim 2$ & 1.7 \\
\hline M (III) & 2.3 & 0.80 & $\sim 2$ & 1.5 \\
\hline M (IV) & 0.8 & 0.07 & $\sim 2$ & 1.3 \\
\hline
\end{tabular}

a some data were obtained from Reiche et al. (2009),

$\mathrm{b}$ no methanogenic activity within 31 days of incubation 


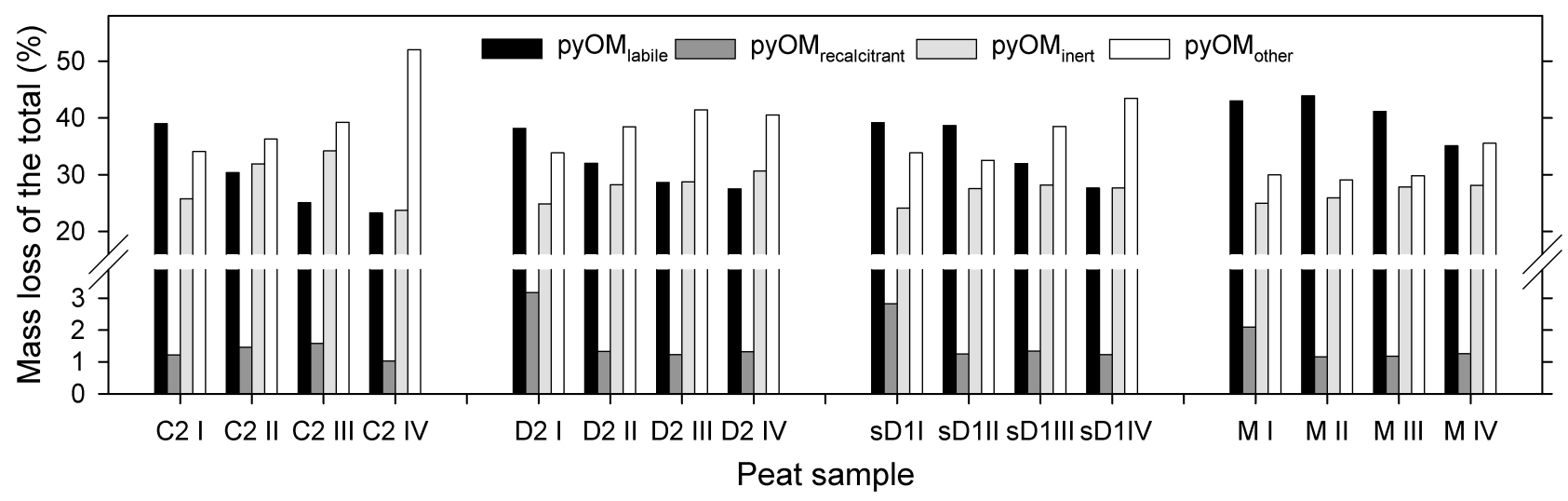

Fig. 2. Percentage of mass loss during thermogravimetry analyses $(n=2)$ over three temperature intervals corresponding to labile carbon

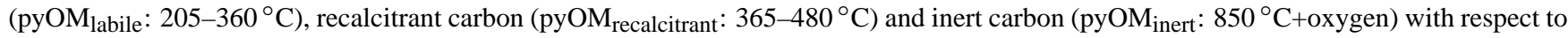
total pyrolyzable organic matter. Mass loss which is not explained by these three temperature intervals is expressed by pyOM $\mathrm{Other}$ Peat was obtained from 4 different sampling sites in an acidic fen along a hydrological gradient (from the middle to the south $\mathrm{C} 2 \rightarrow \mathrm{D} 2 \rightarrow \mathrm{sD} 1 \rightarrow \mathrm{M}$ ) over 4 depths (I: 0-10 cm, II: $10-20 \mathrm{~cm}$, III: $20-30 \mathrm{~cm}$ and IV: $30-40 \mathrm{~cm}$ ).

loss of pyOM $\mathrm{Mabile}_{\text {and }}$ pyOM $\mathrm{M}_{\text {recalcitrant }}$ with pyOM $_{\text {inert }}$ :

$\mathrm{QI}_{\text {peat }}=\frac{\text { pyOM }_{\text {labile }}+\text { pyOM }_{\text {recalcitrant }}}{\text { pyOM }_{\text {inert }}}$

We decided to calculate the $\mathrm{QI}_{\text {peat }}$ as this ratio because pyOM $\mathrm{M}_{\text {labile }}$ and pyOM $_{\text {recalcitrant }}$ correlated positively and pyOM $_{\text {inert }}$ negatively with the corresponding gas formation rates. The fraction of pyOM $\mathrm{M}_{\text {labile }}$ alone was not sufficient to define a precise and robust peat quality index compared to the ratio given above. In principle, the higher the quality index the higher the quantity of labile and recalcitrant organic matter should be. For further comparisons, mass loss which was not described by these three selected temperature intervals was expressed as pyOM $\mathrm{O}_{\text {other }}$ (Fig. 2).

The proportion of pyrolyzable pyOM labile $(38-44 \%)$ tended to be highest in the upper segment $(0-10 \mathrm{~cm})$ at all sampling areas. The lowest segments $(30-40 \mathrm{~cm})$ yielded 23-35\% (Fig. 2). A high proportion of $\mathrm{pyOM}_{\text {labile }}$ in the $10-30 \mathrm{~cm}$ depth segment was found at area M (41-44\%). pyOM $\mathrm{M}_{\text {recalcitrant }}$ reached $2.1-3.2 \%$ in the first peat segment of $\mathrm{D} 2, \mathrm{sD} 1$ and $\mathrm{M}$, which was twice as high as in samples obtained from $\mathrm{C} 2$ or at depths below $10 \mathrm{~cm}$ (Fig. 2). In contrast, the percentage of combustible inert carbon compounds (pyOM $\mathrm{M}_{\text {inert }}$ ) tended to increase with depth from approximately $25 \%$ to more than $28 \%$.

Calculating the peat quality index with respect to these three categories yielded values from 0.8 to 1.8 . The index was highest in peat samples from the upper most peat segment compared with corresponding segments below (Fig. 3). At $\mathrm{SD} 1$ and $\mathrm{M}$, a high index $>1.35$ was also observed up to $30 \mathrm{~cm}$ depth. Quality index was lowest for peat samples below $10 \mathrm{~cm}$ depth at $\mathrm{C} 2$ and $\mathrm{D} 2$. In general, peat of the southern, water-logged sampling areas SD1 and M was less degraded and the amounts of pyOM $_{\text {labile }}$ in depths below $10 \mathrm{~cm}$ were high in comparison with samples obtained from the hydrological and redox instable areas C2 and D2. The mean peat quality index was 1.3 times lower in these areas than in peat samples from sD1 and M (Fig. 3).

\subsection{Major pyrolysis products of peat}

The major Py-GC/MS products of all peat samples and precursor classes, according to the molecule from which each Py-GC/MS product was generated, are given in Table 1. The number of peaks detected during the pyrolysis process increased with depth from $46(0-10 \mathrm{~cm})$ to $64(20-30 \mathrm{~cm})$ at $\mathrm{C} 2$ and from $44(0-10 \mathrm{~cm})$ to $80(30-40 \mathrm{~cm})$ at D2. Peaks at sampling area $M$ between $0-10 \mathrm{~cm}$ and $30-40 \mathrm{~cm}$ depths were as large as 56. The low retention times, between 10.8 and $27.3 \mathrm{~min}$, in the chromatogram of the Py-GC/MS were indicative for toluene, furan, furaldehyde, phenol, and benzene derivates (Table 1). A "lignin region" between 28.9 and $43.6 \mathrm{~min}$ was dominated by methylphenol and methoxyphenol derivates. Compounds with high retention time, 45.6 to $63.2 \mathrm{~min}$, and higher molecular weight dominated the "lipid region", i.e. n-alkens and n-alkans, with a chain length of more than C17. The contribution of carbohydrates, as calculated from the peak area of carbohydrate pyrolysis products, decreased with increasing depth from $20 \%$ to $7 \%$ at $\mathrm{C} 2$ and from $17 \%$ to $6 \%$ at D2 (Fig. 4). Carbohydrates at the most southern sampling area $\mathrm{M}$ reached $18 \%$ and were constant at all measured depths. The contribution of lipids to the total pyrogram increased in deeper segments of D2 and $\mathrm{M}$, whereas lignin and carbohydrate pyrolysis products decreased with depth. Lipid and lignin contribution to the pyrogram of C2 samples reached approximately $24 \%$ at depth I $(0-10 \mathrm{~cm})$ and $35 \%$ at depth III $(20-30 \mathrm{~cm})$. Total pyrolyzable matter in relation to dry matter was approximately $48 \%$ in peat samples obtained from $20-40 \mathrm{~cm}$ depth and 64,48 , 


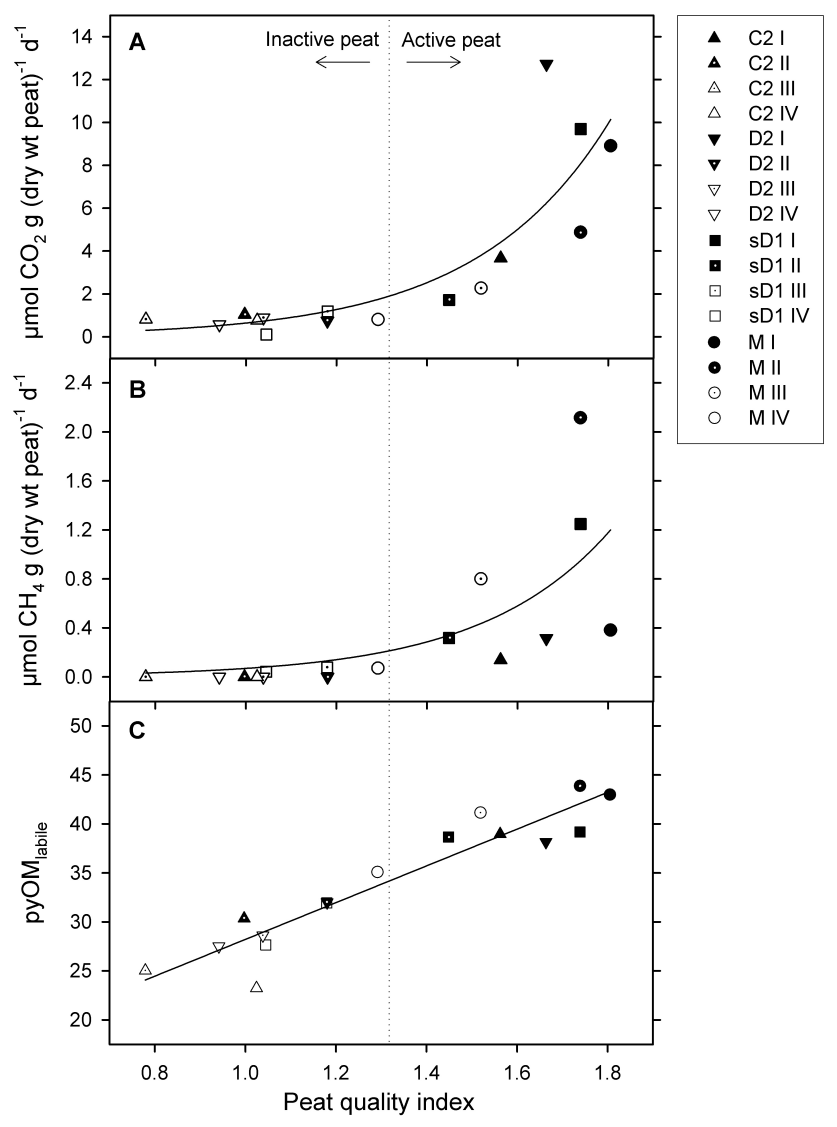

Fig. 3. Correlation of peat quality index as ratio between the sum of thermal labile and recalcitrant $\mathrm{C}$-based compounds and inert carbon compounds, $\left(\mathrm{pyOM}_{\text {labile }}+\mathrm{pyOM}_{\text {recalcitrant }}\right) / \mathrm{pyOM}_{\text {inert }}$, obtained with thermogravimetry analyses with formation rates of $\mathrm{CO}_{2}$ (a) and $\mathrm{CH}_{4}$ (b), and proportion of thermal labile particulate organic matter $\left(\right.$ pyOM $\left._{\text {labile }}\right)(\mathbf{c})$. Peat was sampled at 4 sampling sites along a hydrological gradient of an acidic fen (from the middle to the south $\mathrm{C} 2 \rightarrow \mathrm{D} 2 \rightarrow \mathrm{sD} 1 \rightarrow \mathrm{M}$ ) over 4 depths (I: $0-10 \mathrm{~cm}$, II: 10 $20 \mathrm{~cm}$, III: $20-30 \mathrm{~cm}$ and IV: $30-40 \mathrm{~cm}$ ). The best fit equation for $\mathrm{CO}_{2}$ formation, $\mathrm{CH}_{4}$ formation and $\mathrm{pyOM}_{\text {labile }}$ with peat quality is expressed by: $y=0.025 \mathrm{e}^{3.19 x}\left(r^{2}=0.71, p<0.01\right), y=0.002 \mathrm{e}^{3.54 x}$ $\left(r^{2}=0.49, p<0.01\right)$ and $y=18.75 \mathrm{x}+9.5\left(r^{2}=0.89, p<0.01\right)$, respectively.

$59 \%$ in upper peat depths of C2, D2 and M, respectively. The content of lignin was positively correlated with the anaerobic formation rates of $\mathrm{CO}_{2}(r=0.86, p<0.01)$ and $\mathrm{CH}_{4}$ $(r=0.93, p<0.05)$, whereas the content of lipids were negatively correlated with the anaerobic formation rates of $\mathrm{CO}_{2}$ $(r=-0.84, p<0.01)$ and $\mathrm{CH}_{4}(r=-0.91, p<0.05)$.

\section{Discussion}

\subsection{Peat composition}

The percentage of pyOM $\mathrm{M}_{\text {labile }}$ during TG analyses was highest in the $0-10 \mathrm{~cm}$ segment at C2, D2, and sD1. Similarly, the

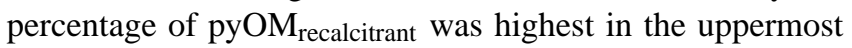
segment at D2, sD1, and M (Fig. 2). This high percentage likely indicates an input of fresh and therefore less decomposed plant litter, i.e. from dead roots and leaves of growing vegetation. This vegetation can further increase the pool of easy available carbon substrates, such as carbohydrates and amino acids, through the leakage of exudates from living plant roots (Grayston et al., 1996; Yan et al., 2008). The large number of detectable peaks obtained with Py-GC/MS at C2 and D2 of the lower segments, compared to the upper peat segments, demonstrated a high complexity of organic matter in deep peat segments. Additionally, the increased percentage of unspecific pyrolysis products in depths below $10 \mathrm{~cm}$ was indicative of more humified peat.

In all pyrograms, lipids, lignin, and to a lesser extent, carbohydrates, were the major pyrolysis precursors (Fig. 4 and Table 1). Large amounts of long-chain lipids accumulated in deeper peat segments (Fig. 4 and Table 1). Several studies have shown that aliphatic biopolymers are highly resistant to biodegradation and can be well preserved in soils (Gleixner et al., 2001; Winkler et al., 2005; Otto and Simpson, 2006). The high proportion of linear alkane/alkene peaks in the PyGC/MS data in peat segments below $10 \mathrm{~cm}$ at D2 and M suggested that aliphatic polymer material is an important part of the lower peat organic matter (Fig. 4 and Table 1). Alkanes/alkenes with chain lengths of more than C16 are common compounds that originate from plant aliphatic polymers such as leaf and root waxes, like cutin- and suberin-derived polymers (Nip et al., 1986; Tegelaar et al., 1995; Gleixner et al., 2001; Kögel-Knabner, 2002). The proportion of carbohydrates in deeper peat segments (II, III, IV) represented more than $30 \%$ of the relative carbohydrate proportion in peat segment I suggesting carbohydrate degradation throughout the profile, probably caused my microbial mineralization. However, we observed almost no difference in the patterns of carbohydrate-related peaks in the different peat segments. Carbohydrates are known to be recycled or newly formed in soils during decomposition (Gleixner et al., 2002) and this may also occur in peat (Kracht and Gleixner, 2000).

\subsection{Microbial formation of $\mathrm{CO}_{2}$ and $\mathrm{CH}_{4}$}

This fen site has been investigated intensively within a national interdisciplinary research group since 2001. According to previous investigations (Küsel et al., 2008; Reiche et al., 2008, 2009), $\mathrm{CO}_{2}$ and $\mathrm{CH}_{4}$ formation rates were highly spatially variable and depended neither on peat depth or the hydrological gradient at this site. In all areas, anaerobic $\mathrm{CO}_{2}$ formation rates were highest in the upper peat segments, 


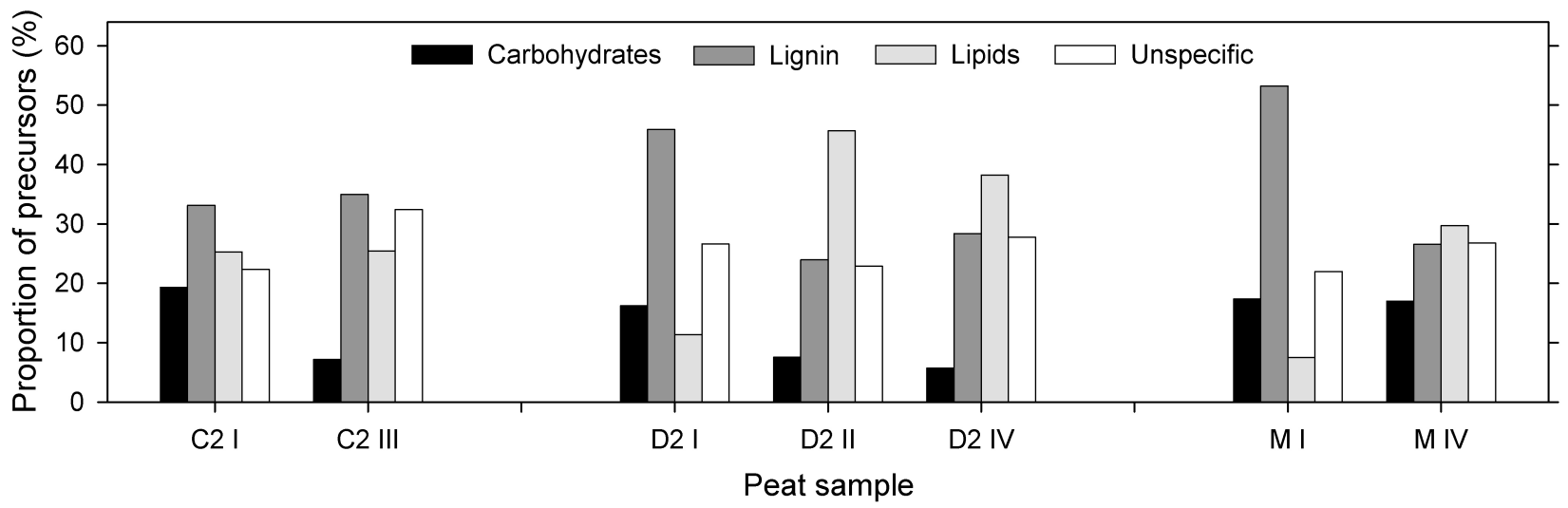

Fig. 4. Relative proportion (\% of total pyrolyzable compounds) of identified compounds grouped by precursor classes of chemical compounds (carbohydrates, lignin, lipids and unspecific C-based compounds) from different peat samples obtained from an acidic fen (C2: middle part, D2: more southern part, M: most southern part) over 4 depths (I: 0-10 cm, II: $10-20 \mathrm{~cm}$, III: $20-30 \mathrm{~cm}$ and IV: $30-40 \mathrm{~cm}$ ). Compounds were identified using Curie-point pyrolysis-gas chromatography/mass spectrometry $(n=2)$.

suggesting favorable conditions for microorganisms in the segment most influenced by growing vegetation. Positive correlation of $\mathrm{CO}_{2}$ formation rates with the total amounts of Fe confirmed that high Fe(III)-reducing activity in the upper most peat segment (Küsel et al., 2008) may contribute to anaerobic $\mathrm{CO}_{2}$ formation. The positive correlation of $\mathrm{CO}_{2}$ formation rates with $\mathrm{Al}$ and $\mathrm{Ca}$ in this study can not be attributed to a microbial respiratory process and are better explained by co-precipitation with $\mathrm{Fe}(\mathrm{III})$-oxides during oxygenation or drying events.

Peat below $10 \mathrm{~cm}$ depth at $\mathrm{C} 2$ and D2 did not form $\mathrm{CH}_{4}$ during an incubation period of 31 days. In addition, the $\mathrm{CO}_{2}$ formation rates were very low, although numbers of DAPI counted cells were in the same order of magnitude as in segment I. Peat sampled at areas SD1 and $\mathrm{M}$ decreased in $\mathrm{CH}_{4}$ formation rates with increasing depth, similar to other peatlands (Hughes et al., 1999; van den Pol-van Dasselaar and Oenema, 1999; Chow et al., 2006). The activity of methanogenically-active peat segments was in the range as has been reported for boreal peatlands (Bergman et al., 2000; Galand et al., 2005; Metje and Frenzel, 2007; Rooney-Varga et al., 2007). In general, northern wetland $\mathrm{CH}_{4}$ emissions contribute 10-44 Tg of the greenhouse gas methane $\left(\mathrm{CH}_{4}\right)$ annually (Mikaloff Fletcher et al., 2004; Zhuang et al., 2004; Walter et al., 2006). The long onset of $\mathrm{CH}_{4}$ formation in the upper peat segments and the low to negligible $\mathrm{CH}_{4}$ forming activity of deeper peat segments suggested that $\mathrm{CH}_{4}$ production is not a significant pathway of carbon flow out of this fen. The high spatial heterogeneity of the rates observed even within a small field site like this fen suggests a need for more replicate studies of $\mathrm{CO}_{2}$ and $\mathrm{CH}_{4}$ emission rates. Adequate assessment of the contribution of peatlands to the global $\mathrm{CO}_{2}$ and $\mathrm{CH}_{4}$ budget will require not only field measurements of gas fluxes over the complete season and a wide range of different peatland sites for $\mathrm{CH}_{4}$ fluxes (Crill et al., 1988), but also at different areas within the same peatland site.

\subsection{Link of peat quality to microbial activity}

The quality of organic matter is a key factor controlling the rate of organic matter mineralization (Yavitt and Lang, 1990; Bridgham and Richardson, 1992; Crozier et al., 1995; Wagner et al., 2005). The poor substrate quality of highly decomposed, humified peat limits both $\mathrm{CO}_{2}$ and $\mathrm{CH}_{4}$ production rates, even though the peat can be up to $95 \%$ organic matter (Bridgham and Richardson, 1992). Many quality indexes have been proposed in the past, but there is currently no common definition or widely accepted quantitative index of "quality" (Rubino et al., 2007). For example, the ratio of $\mathrm{C}$ to $\mathrm{N}$ concentration $(\mathrm{C}: \mathrm{N}$ ratio) or the ratio of lignin to $\mathrm{N}$ concentration (lignin:N ratio), have been frequently used as an index of litter quality (Taylor et al., 1989; Enriquez et al., 1993; Valentine et al., 1994; Gholz et al., 2000; Moore et al., 2007). Lignin: $N$ ratios can provide a modest explanation of peat decomposition rates (Moore et al., 2005). In this study, the anaerobic $\mathrm{CO}_{2}$ formation rates observed correlated negatively with their corresponding $\mathrm{C}: \mathrm{N}$ ratios $(r=-0.60$, $p<0.05$ ), but did not with the lignin: $\mathrm{N}$ ratios. In contrast, $\mathrm{CH}_{4}$ formation rates did not correlate with $\mathrm{C}: \mathrm{N}$ or lignin:N ratios. However, the low $\mathrm{C}: \mathrm{N}$ ratios in the upper peat segment (Table 2) suggested a higher peat quality than in depths below. Other correlations indicated that less decomposed plant biomass rich in lignin and poor in lipids at area $\mathrm{M}$ and in upper peat of areas $\mathrm{C}$ and $\mathrm{D}$ is a prerequisite for $\mathrm{CO}_{2}$ and $\mathrm{CH}_{4}$ formation in this fen. This finding was confirmed by the Von Post's humification scale (Clymo, 1983). However, this was not sufficient to explain small spatial differences of $\mathrm{CO}_{2}$ and $\mathrm{CH}_{4}$ formation at all depths. Although there are indications that the degree of humification may be an important control of $\mathrm{CO}_{2}$ and $\mathrm{CH}_{4}$ production (Glatzel et al., 2004), we did not find a clear relationship which would allow a clear prediction of $\mathrm{CO}_{2}$ and $\mathrm{CH}_{4}$ production rates under anoxic conditions. This finding was also previously reported (Moore and Dalva, 1997). 
The TG measurements showed that peat quality in relation to biological function can be described as ratio between the sum of labile and recalcitrant carbon compounds and the proportion of highly humified inert C-based compounds. In principle, the lower the quality index, the higher the quantity of inert C-based compounds in the peat should be. Consequently, peat with a high quality index will also show higher concentrations of easily biodegradable organic matter from either $\mathrm{pyOM}_{\text {labile }}$ or pyOM $\mathrm{M}_{\text {recalcitrant }}$.

The thermal degradability of peat obtained with TG might not agree with microbial availability of peat organic matter and does not explain differences in the onset of $\mathrm{CH}_{4}$ formation. However, assuming that the fraction of pyOM $\mathrm{M}_{\text {labile }}$ represents easily available substrates for microorganisms (Gleixner et al., 2002), our results showed that peat was active in anaerobic $\mathrm{CO}_{2}$ and $\mathrm{CH}_{4}$ formation when this fraction was above $35 \%$ and the $\mathrm{QI}_{\text {peat }}$ was above 1.35. Correlating TG with Py-GC/MS data suggested that carbohydrates were a relevant part of the pyOM $\mathrm{Mabile}_{\text {le }}(r=0.87, p<0.05)$. A positive correlation $(r=0.88, p<0.01)$ with $\mathrm{CO}_{2}$ formation was also found with the fraction of pyOM recalcitrant. This indicated that thermally recalcitrant carbon compounds can be also efficiently used as a carbon source by microorganisms.

The new peat quality index was successfully used to estimate the potential formation of the greenhouse gases $\mathrm{CO}_{2}$ and $\mathrm{CH}_{4}$ at four areas from this fen. Although it only ranged from 0.8 to 1.8 , this small range may be enlarged depending on the proportion of the pyOM fractions resulting from the diverse botanical origins of peat organic matter found in other peatlands. How stable this current peat quality index is with respect to the potential $\mathrm{CO}_{2}$ and $\mathrm{CH}_{4}$ formation is still an open question. Mesocosm experiments indicate that a change in the size and/or quality of the labile carbon pool can occur relatively quickly (less than 6 years) (Keller et al., 2004). More research on different types of peatlands, i.e. Sphagnum-peat bogs, boreal peatlands, Siberian bogs, and degradated peatland sites is needed to confirm whether this new quality index can be used to estimate the potential greenhouse gas formation of peatlands in general.

\section{Conclusions}

Although parameters like water table depth, moisture content, loss on ignition, and the $\mathrm{C}: \mathrm{N}$ ratio are easy to determine and can be correlated in several cases with the potential formation rates of $\mathrm{CO}_{2}$ and $\mathrm{CH}_{4}$, they are often not sufficient to explain small spatial heterogeneities in greenhouse gas formation. Our new peat quality index was an easy tool to estimate the potential greenhouse gas formation for both $\mathrm{CO}_{2}$ and $\mathrm{CH}_{4}$. The content of thermally labile and recalcitrant organic compounds appeared to be the most important factor controlling $\mathrm{CO}_{2}$ and $\mathrm{CH}_{4}$ formation. Therefore, the direct link presented here between peat quality and microbial $\mathrm{CO}_{2}$ and $\mathrm{CH}_{4}$ formation should facilitate predictions with a ro- bust theoretical basis for modeling and calculating element cycles or trace gas fluxes from peatlands for climate change research.

Acknowledgements. We thank S. Rühlow and J. Kirschstein for technical assistance and support during Py-GC/MS and TG measurements. The authors thank J. Gelbrecht (IGB Berlin) for providing technical equipment and P. Bouwma for critical reading. This work is part of the research group FOR 562 "Dynamics of soil processes under extreme meteorological boundary conditions" supported by the Deutsche Forschungsgemeinschaft DFG.

Edited by: A. Neftel

\section{References}

AIST: Integrated Spectral Data Base System for Organic Compounds (SDBS), 2001.

Aselmann, I. and Crutzen, P. J.: Global distribution of natural freshwater wetlands and rice paddies, their net primary productivity, seasonality and possible methane emissions, J. Atmos. Chem., 8, 307-358, 1989.

Bergman, I., Klarqvist, M., and Nilsson, M.: Seasonal variation in rates of methane production from peat of various botanical origins: effects of temperature and substrate quality, FEMS Microbiol. Ecol., 33, 181-189, 2000.

Bohlin, E., Hamalainen, M., and Sunden, T.: Botanical and chemical characterization of peat using multivariate methods, Soil Sci., 147, 252-263, 1989.

Botch, M. S., Kobak, K. I., Vinson, T. S., and Kolchugina, T. P.: Carbon pools and accumulation in peatlands of the former Soviet-Union, Global Biogeochem. Cy., 9, 37-46, 1995.

Bridgham, S. D. and Richardson, C. J.: Mechanisms controlling soil respiration $\left(\mathrm{CO}_{2}\right.$ and $\left.\mathrm{CH}_{4}\right)$ in southern peatlands, Soil Biol. Biochem., 24, 1089-1099, 1992.

Charman, D. J., Aravena, R., Bryant, C. L., and Harkness, D. D.: Carbon isotopes in peat, $\mathrm{DOC}, \mathrm{CO}_{2}$, and $\mathrm{CH}_{4}$ in a holocene peatland on Dartmoor, southwest England, Geology, 27, 539-542, 1999.

Chow, A. T., Tanji, K. K., Gao, S. D., and Dahlgren, R. A.: Temperature, water content and wet-dry cycle effects on DOC production and carbon mineralization in agricultural peat soils, Soil Biol. Biochem., 38, 477-488, 2006.

Christensen, T. R., Ekberg, A., Strom, L., Mastepanov, M., Panikov, N., Mats, O., Svensson, B. H., Nykanen, H., Martikainen, P. J., and Oskarsson, H.: Factors controlling large scale variations in methane emissions from wetlands, Geophys. Res. Lett., 30, 1414, doi:10.1029/2002L016848, 2003.

Clymo, R. S.: Peat, in: Ecosystems of the world , 4A, Mires: Swamp, bog, fen and moor, edited by: Gore, A. J. P., Elsevier, Amsterdam, 159-224, 1983.

Crill, P. M., Bartlett, K. B., Harriss, R. C., Gorham, E., Verry, E. S., Sebacher, D. I., Madzar, L., and Sanner, W.: Methane flux from Minnesota peatlands, Global Biogeochem. Cy., 2, 371-384, 1988.

Crozier, C. R., Devai, I., and Delaune, R. D.: Methane and reduced sulfur gas-production by fresh and dried wetland soils, Soil Sci. Soc. Am. J., 59, 277-284, 1995. 
Dell'Abate, M. T., Canali, S., Trinchera, A., Benedetti, A., and Sequi, P.: Thermal analysis in the evaluation of compost stability: A comparison with humification parameters, Nutr. Cycl. Agroecosys., 51, 217-224, 1998.

Dell'Abate, M. T., Benedetti, A., Trinchera, A., and Dazzi, C.: Humic substances along the profile of two Typic Haploxerert, Geoderma, 107, 281-296, 2002.

Dell'Abate, M. T., Benedetti, A., and Brookes, P. C.: Hyphenated techniques of thermal analysis for characterisation of soil humic substances, J. Sep. Sci., 26, 433-440, 2003.

Enriquez, S., Duarte, C. M., and Sandjensen, K.: Patterns in decomposition rates among photosynthetic organisms - The importance of detritus C-N-P content, Oecologia, 94, 457-471, 1993.

Fernandez, J. M., Hockaday, W. C., Plaza, C., Polo, A., and Hatcher, P. G.: Effects of long-term soil amendment with sewage sludges on soil humic acid thermal and molecular properties, Chemosphere, 73, 1838-1844, doi:10.1016/j.chemosphere.2008.08.001, 2008.

Galand, P. E., Fritze, H., Conrad, R., and Yrjala, K.: Pathways for methanogenesis and diversity of methanogenic archaea in three boreal peatland ecosystems, Appl. Environ. Microb., 71, 21952198, 2005.

Gholz, H. L., Wedin, D. A., Smitherman, S. M., Harmon, M. E., and Parton, W. J.: Long-term dynamics of pine and hardwood litter in contrasting environments: Toward a global model of decomposition, Glob. Change Biol., 6, 751-765, 2000.

Glatzel, S., Basiliko, N., and Moore, T.: Carbon dioxide and methane production potentials of peats from natural, harvested, and restored sites, eastern Quebec, Canada, Wetlands, 24, 261267, 2004.

Gleixner, G., Bol, R., and Balesdent, J.: Molecular insight into soil carbon turnover, Rapid Commun. Mass Sp., 13, 1278-1283, 1999.

Gleixner, G., Czimczik, C. J., Kramer, C., Lühker, B., and Schmidt, M. W. I.: Plant Compounds and their Turnover and Stabilization as Soil Organic Matter, in: Global Biogeochemical Cycles in the Climate System, edited by: Schulze, E. D., Heimann, M., Harrison, S., Holland, E. A., Lloyd, J., Prentice, I. C., and Schimel, D. S., Academic Press, San Diego, 201-215, 2001.

Gleixner, G., Poirier, N., Bol, R., and Balesdent, J.: Molecular dynamics of organic matter in a cultivated soil, Org. Geochem., 33, 357-366, 2002.

Gorham, E.: Northern peatlands - role in the carbon-cycle and probable responses to climatic warming, Ecol. Appl., 1, 182-195, 1991.

Grayston, S. J., Vaughan, D., and Jones, D.: Rhizosphere carbon flow in trees, in comparison with annual plants: The importance of root exudation and its impact on microbial activity and nutrient availability, Appl. Soil Ecol., 5, 29-56, 1996.

Grisi, B., Grace, C., Brookes, P. C., Benedetti, A., and Dell'Abate, M. T.: Temperature effects on organic matter and microbial biomass dynamics in temperate and tropical soils, Soil Biol. Biochem., 30, 1309-1315, 1998.

Houghton, J.: Global warming, Rep. Prog. Phys., 68, 1343-1403, 2005.

Hughes, S., Dowrick, D. J., Freeman, C., Hudson, J. A., and Reynolds, B.: Methane emissions from a gully mire in midWales, UK under consecutive summer water table drawdown, Environ. Sci. Technol., 33, 362-365, 1999.
Keller, J. K., White, J. R., Bridgham, S. D., and Pastor, J.: Climate change effects on carbon and nitrogen mineralization in peatlands through changes in soil quality, Glob. Change Biol., 10, 1053-1064, 2004.

Kögel-Knabner, I.: The macromolecular organic composition of plant and microbial residues as inputs to soil organic matter, Soil Biol. Biochem., 34, 139-162, 2002.

Kracht, O. and Gleixner, G.: Isotope analysis of pyrolysis products from Sphagnum peat and dissolved organic matter from bog water, Org. Geochem., 31, 645-654, 2000.

Küsel, K., Blöthe, M., Schulz, D., Reiche, M., and Drake, H. L.: Microbial reduction of iron and porewater biogeochemistry in acidic peatlands, Biogeosciences, 5, 1537-1549, 2008, http://www.biogeosciences.net/5/1537/2008/.

Lopez-Capel, E., Sohi, S. P., Gaunt, J. L., and Manning, D. A. C.: Use of thermogravimetry-differential scanning calorimetry to characterize modelable soil organic matter fractions, Soil Sci. Soc. Am. J., 69, 136-140, 2005.

McLafferty, F. W.: Wiley registry of mass spectral data, 6th Edn., 2001.

Metje, M. and Frenzel, P.: Methanogenesis and methanogenic pathways in a peat from subarctic permafrost, Environ. Microbiol., 9, 954-964, 2007.

Mikaloff Fletcher, S. E., Tans, P. P., Bruhwiler, L. M., Miller, J. B., and Heimann, M.: $\mathrm{CH}_{4}$ sources estimated from atmospheric observations of $\mathrm{CH}_{4}$ and its ${ }^{13} \mathrm{C} /{ }^{12} \mathrm{C}$ isotopic ratios: 1 . Inverse modeling of source processes, Global Biogeochem. Cy., 18, Gb4004, doi:4010.1029/2004gb002223, 2004.

Moore, T. R. and Knowles, R.: Methane emissions from fen, bog and swamp peatlands in Quebec, Biogeochemistry, 11, 45-61, 1990.

Moore, T. R., Roulet, N. T., and Knowles, R.: Spatial and temporal variation on methane flux from subarctic/northern boreal fens, Global Biogeochem. Cy., 4, 29-46, 1990.

Moore, T. R. and Dalva, M.: Methane and carbon dioxide exchange potentials of peat soils in aerobic and anaerobic laboratory incubations, Soil Biol. Biochem., 29, 1157-1164, 1997.

Moore, T. R., Trofymow, J. A., Siltanen, M., and Prescott, C.: Patterns of decomposition and carbon, nitrogen, and phosphorus dynamics of litter in upland forest and peatland sites in central Canada, Can. J. Forest Res., 35, 133-142, 2005.

Moore, T. R., Bubier, J. L., and Bledzki, L.: Litter decomposition in temperate peatland ecosystems: The effect of substrate and site, Ecosystems, 10, 949-963, 2007.

Nip, M., Tegelaar, E. W., Brinkhuis, H., Deleeuw, J. W., Schenck, P. A., and Holloway, P. J.: Analysis of modern and fossil plant cuticles by Curie-point Py-GC and Curie-point Py-GC-MS - Recognition of a new, highly aliphatic and resistant bio-polymer, Org. Geochem., 10, 769-778, 1986.

NIST: NIST Chemistry WebBook, 2002.

Otto, A. and Simpson, M. J.: Sources and composition of hydrolysable aliphatic lipids and phenols in soils from western Canada, Org. Geochem., 37, 385-407, 2006.

Paul, S., Küsel, K., and Alewell, C.: Reduction processes in forest wetlands: Tracking down heterogeneity of source/sink functions with a combination of methods, Soil Biol. Biochem., 38, 10281039, 2006.

Petrescu, A. M. R., van Huissteden, J., Jackowicz-Korczynski, M., Yurova, A., Christensen, T. R., Crill, P. M., Bäckstrand, K., and 
Maximov, T. C.: Modelling $\mathrm{CH}_{4}$ emissions from arctic wetlands: effects of hydrological parameterization, Biogeosciences, 5, 111-121, 2008, http://www.biogeosciences.net/5/111/2008/.

Plante, A. F., Pernes, M., and Chenu, C.: Changes in clayassociated organic matter quality in a $\mathrm{C}$ depletion sequence as measured by differential thermal analyses, 129, 186-199, doi:10.1016/j.geoderma.2004.12.043, 2005.

Plante, A. F., Fernandez, J. M., and Leifeld, J.: Application of thermal analysis techniques in soil science, Geoderma, 153, 1-10, doi:10.1016/j.geoderma.2009.08.016, 2009.

Pope, M. I. and Judd, M. J.: Differential thermal analysis, Academic Press, London, 1977.

Reiche, M., Torborg, G., and Küsel, K.: Competition of Fe(III) reduction and methanogenesis in an acidic fen, FEMS Microbiol. Ecol., 65, 88-101, 2008.

Reiche, M., Hädrich, A., Liescheid, G., and Küsel, K.: Impact of manipulated drought and heavy rainfall events on peat mineralization processes and source-sink functions of an acidic fen, J. Geophys. Res.-Bio., 114, doi:10.1029/2008JG000853, 2009.

Rooney-Varga, J. N., Giewat, M. W., Duddleston, K. N., Chanton, J. P., and Hines, M. E.: Links between archaeal community structure, vegetation type and methanogenic pathway in Alaskan peatlands, FEMS Microbiol. Ecol., 60, 240-251, 2007.

Roulet, N., Moore, T., Bubier, J., and Lafleur, P.: Northern fens Methane flux and climatic change, Tellus B, 44, 100-105, 1992a.

Roulet, N. T., Ash, R., and Moore, T. R.: Low boreal wetlands as a source of atmospheric methane, J. Geophys. Res.-Atmos., 97, 3739-3749, 1992b.

Rubino, M., Lubritto, C., D’Onofrio, A., Terrasi, F., Gleixner, G., and Cotrufo, M. F.: An isotopic method for testing the influence of leaf litter quality on carbon fluxes during decomposition, Oecologia, 154, 155-166, 2007.

Schulten, H. R. and Gleixner, G.: Analytical pyrolysis of humic substances and dissolved organic matter in aquatic systems: Structure and origin, Water Res., 33, 2489-2498, 1999.

Steinbeiss, S., Schmidt, C. M., Heide, K., and Gleixner, G.: Delta $\mathrm{C}-13$ values of pyrolysis products from cellulose and lignin represent the isotope content of their precursors, J. Anal. Appl. Pyrol., 75, 19-26, 2006.

Strack, M. and Waddington, J. M.: Response of peatland carbon dioxide and methane fluxes to a water table drawdown experiment, Glob. Biogeochem. Cy., 21, GB1007, doi:10.1029/2006GB002715, 2007.

Svensson, B. H. and Rosswall, T.: In situ methane production from acid peat in plant-communities with different moisture regimes in a subarctic mire, Oikos, 43, 341-350, 1984.

Taylor, B. R., Parkinson, D., and Parsons, W. F. J.: Nitrogen and lignin content as predictors of litter decay-rates - A microcosm test, Ecology, 70, 97-104, 1989.

Tegelaar, E. W., Hollman, G., Vandervegt, P., Deleeuw, J. W., and Holloway, P. J.: Chemical characterization of the periderm tissue of some angiosperm species - recognition of an insoluble, nonhydrolyzable, aliphatic biomacromolecule (suberan), Org. Geochem., 23, 239-251, 1995.
Turunen, J., Tomppo, E., Tolonen, K., and Reinikainen, A.: Estimating carbon accumulation rates of undrained mires in Finland - application to boreal and subarctic regions, Holocene, 12, 6980, 2002.

Valentine, D. W., Holland, E. A., and Schimel, D. S.: Ecosystem and physiological controls over methane production in northern wetlands, J. Geophys. Res.-Atmos., 99, 1563-1571, 1994.

van den Pol-van Dasselaar, A. and Oenema, O.: Methane production and carbon mineralisation of size and density fractions of peat soils, Soil Biol. Biochem., 31, 877-886, 1999.

Wagner, D., Lipski, A., Embacher, A., and Gattinger, A.: Methane fluxes in permafrost habitats of the Lena Delta: Effects of microbial community structure and organic matter quality, Environ. Microbiol., 7, 1582-1592, 2005.

Walter, B. P. and Heimann, M.: A process-based, climate-sensitive model to derive methane emissions from natural wetlands: Application to five wetland sites, sensitivity to model parameters, and climate, Global Biogeochem. Cy., 14, 745-765, 2000.

Walter, K. M., Zimov, S. A., Chanton, J. P., Verbyla, D., and Chapin, F. S.: Methane bubbling from Siberian thaw lakes as a positive feedback to climate warming, Nature, 443, 71-75, doi:10.1038/nature05040, 2006.

Whalen, S. C. and Reeburgh, W. S.: A methane transect along the trans-Alaskan pipeline haul road, Tellus B, 42, 237-249, 1990.

Whiting, G. J. and Chanton, J. P.: Primary production control of methane emission from wetlands, Nature, 364, 794-795, 1993.

Winkler, A., Haumaier, L., and Zech, W.: Insoluble alkyl carbon components in soils derive mainly from cutin and suberin, Org. Geochem., 36, 519-529, 2005.

Yan, W., Artz, R. R. E., and Johnson, D.: Species-specific effects of plants colonising cutover peatlands on patterns of carbon source utilisation by soil microorganisms, Soil Biol. Biochem., 40, 544549, 2008.

Yavitt, J. B., Lang, G. E., and Wieder, R. K.: Control of carbon mineralization to $\mathrm{CH}_{4}$ and $\mathrm{CO}_{2}$ in anaerobic, Sphagnumderived peat from Big Run Bog, West-Virginia, Biogeochemistry, 4, 141-157, 1987.

Yavitt, J. B. and Lang, G. E.: Methane production in contrasting wetland sites - Response to organic-chemical components of peat and to sulfate reduction, Geomicrobiol. J., 8, 27-46, 1990.

Zeikus, J. G.: Metabolic communication between biodegradative populations in nature, in: Microbes in their natural environment, edited by: Slater, J. H., Whittenbury, R., and Wimpenny, J. W. T., Cambridge University Press, Cambridge, 423-462, 1983.

Zhuang, Q., Melillo, J. M., Kicklighter, D. W., Prinn, R. G., McGuire, A. D., Steudler, P. A., Felzer, B. S., and Hu, S.: Methane fluxes between terrestrial ecosystems and the atmosphere at northern high latitudes during the past century: A retrospective analysis with a process-based biogeochemistry model, Global Biogeochem. Cy., 18, Gb3010, doi:10.1029/2004gb002239, 2004. 